\title{
VOLATILNOST VOZARINA U KONTEJNERSKOM POMORSKOM PROMETU U DOBA PANDEMIJE COVID-19
}

\author{
Dora Naletina ${ }^{17}$
}

UDC / UDK: 656.61:656.073.235:616.9

JEL classification / JEL klasifikacija: R40

DOI: https://doi.org/10.22598/pi-be/2021.15.2.105

Scientific review / Pregledni znanstveni rad

Received / Primljeno: September 27, 2021 / 27. rujna 2021.

Accepted for publishing / Prihvaćeno za tisak: November 29, 2021 / 29. studenog 2021.

\section{Sažetak}

Posljednjih godina stabilnost opskrbnih lanaca ugrožena je uslijed raznih pritisaka. Iako se disrupcije u opskrbnim lancima u pravilu javljaju povremeno, imaju velik utjecaj na porast troškova te stvaranje snažnih poremećaja u poslovanju. Pandemija COVID-19 uzdrmala je svjetski opskrbni lanac kako ranije nije videno. Na tako iznenadan šok adekvatno nisu mogla odgovoriti čak ni poduzeća s uspostavljenim visoko kvalitetnim sustavima upravljanja rizikom. Godinama se najveći dio svjetske robne razmjene odvija pomorskim putem ponajprije zbog učinkovitosti te ekonomičnosti koju isti nudi. Uslijed pandemije COVID-19 došlo je do značajnijih promjena na tržištu što je rezultiralo ranije nezabilježenim rastom vozarina u kontejnerskom pomorskom prometu. Rast vozarina na ovom tržištu predstavlja globalni problem jer će se isti, razmjerno o uključenosti pojedinih potrošačkih dobara u opskrbne lance, odraziti i na njihove cijene. Oporavak cjelokupnog svjetskog gospodarstva je ugrožen ovako visokim vozarinama u kontejnerskom pomorskom prometu, a i dodatno ugrožava stabilnost opskrbnih lanaca. Stoga je u fokusu ovog rada volatilnost vozarina na kontejnerskom pomorskom tržištu koja se javila uslijed pandemije COVID-19.

Ključne riječi: disrupcije; opskrbni lanac; kontejnerski pomorski promet; pandemija COVID-19.

\section{UVOD}

Opskrbni lanac predstavlja vrlo kompleksan sustav, a čija je stabilnost posljednjih godina ugrožena uslijed raznih pritisaka. Disrupcije u opskrbnim lancima u

17 Dora Naletina, PhD, Assistant Professor, Faculty of Economics and Business, University of Zagreb, Croatia, E-mail: dvuletic@net.efzg.hr 
pravilu se javljaju povremeno, ali ono što im je uvijek karakteristika je utjecaj na porast troškova odnosno stvaranje snažnih poremećaja u poslovanju. Pokazalo se kako poremećaji uzrokovani COVID-19 virusom (koronavirusom) mogu imati znatno veći utjecaj od poremećaja s kojima su se poduzeća suočavala ranije. Unatoč tome što većina poduzeća kontinuirano upravlja rizicima te teži razviti adekvatan stupanj otpornosti na promjene iz okruženja, nitko nije mogao predvidjeti poremećaje na tržištu kakve je uzrokovala pandemija COVID-19 (McMaster i sur., 2020, Barleta i Sánchez, July 2021), a koja je taj status stekla 11. ožujka 2020. godine (World Health Organization, 11.03.2020.).

Društvene i ekonomske posljedice ove pandemije proširile su se globalno gotovo jednako brzo kao što se je proširio i sam virus (Cullinane \& Haralambides, 2021). Ova pandemija utjecala je na porast vozarina u pomorskom kontejnerskom prometu kakav ranije nije bio zabilježen, a dodatno je na rast vozarina utjecalo i zatvaranje Sueskog kanala tijekom ožujka 2021. godine (Stevens, 29.03.2021.). Kontejnerski brod koji je zablokirao Sueski kanal, odgodio je kretanje brodova koji su išli prema Europi te je dodatno ograničio brodske i lučke kapacitete (United Nations, 2021: XV). Općenito je oporavak cjelokupnog svjetskog gospodarstva ugrožen snažnim rastom vozarina u pomorskom kontejnerskom prometu (UNCTAD Communications and Information Unit, 2021/040), a isti je dodatno uzrokovao poremećaje u opskrbnom lancu. Za očekivati je kako će rast vozarina utjecati i na rast cijena proizvoda koje upravo na tržišta svoje konačne potrošnje dolaze u konetjnerima pomorskim putem. Pomorski prijevoz predstavlja, najzastupljeniju prometnu granu koja je neophodna za svjetsku trgovinu. Upravo se pomorskim putem preveze više od $80 \%$ svjetske robne razmjene (United Nations, 2020), a što najbolje implicira kakve posljedice na brojna gospodarstva može imati rast vozarina u kontejnerskom pomorskom prometu. Osim učinkovitosti koju nudi pomorski prijevoz, ekonomičnost je također bila ključna karakteristika koja je ovoj vrsti prijevoza omogućila središnju ulogu u funkcioniranju svjetske robne razmjene (International Chamber of Shipping, N/A). Sukladno ranije navedenom u fokusu ovog rada je analiza volatilnosti vozarina u kontejnerskom pomorskom prometu za vrijeme pandemije uzrokovane COVID-19 virusom.

Prilikom izrade rada korišteni su dostupni sekundarni podaci preuzeti iz stručnih i znanstvenih časopisa, kao i publikacija Međunarodne pomorske organizacije te Ujedinjenih naroda. Nakon uvodnog dijela, slijedi pregled literature koja u fokusu ima pomorsko tržište u pandemijsko doba. U sklopu trećeg poglavlja daje se osvrt utjecaja kriza na pomorsko kontejnersko tržište, a potom se analiziraju vozarine na kontejnerskom pomorskom tržištu. U četvrtom poglavlju iznesena su zaključna razmatranja.

\section{PREGLED ISTRAŽIVANJA O UTJECAJU PANDEMIJE COVID-19 NA KONTEJNERSKO POMORSKO TRŽIŠTE}

U cilju da omogući svjetskim gospodarstvima nesmetano funkcioniranje, pomorska industrija je posljednjih desetak godina, uspostavila visoko sofisticirane logističke lance kako bi omogućila isporuku robe na vrijeme kako proizvođačima tako i 
krajnjim potrošačima (International Chamber of Shipping, N/A). Pandemija COVID-19 je, unatoč uspostavljenom visokom stupnju sofisticiranosti opskrbnih lanaca, na pomorskom tržištu uzrokovala znatne poremećaje. S druge strane Grzelakowski (2020) ističe kako je neravnoteža na kontejnerskom pomorskom tržištu uobičajen fenomen koji nastaje zbog oscilacija na strani potražnje, dok je ponuda relativno stabilna. No, Cullinane i Haralambides (2021) navode kako su lučke i transportne mreže bile nespremne za tako brzu tranziciju potražnje koja se javila u ovoj pandemiji. Tako je u rujnu, listopadu i studenom 2020. godine većina luka prijavila rekordne razine prometa, no u mjesecima koje su im prethodile bile su suočene s velikim padom potražnje. Rad od kuće i kupnja putem Interneta postavili su izazovne zahtjeve pred opskrbne lance (UNCTAD, 2021/040). Obzirom da većina sudionika na tržištu nije bila pripremljena na ovakvu volatilnost u potražnji, lanci opskrbe su se suočili s nedostatkom opreme, vozača kamiona i radne snage u pristaništu. Uslijed toga počela su se stvarati zagušenja, a vrijeme obrtaja se znatno produljilo. Ova pandemija pokazala je koliko su zapravo ranjivi lanci opskrbe. Brojna poduzeća u Europi i Sjedinjenim Američkim Državama počela su se fokusirati na lokalizaciju, 3-D ispise te približavanje mjesta proizvodnje kao i uspostavu bolje povezanosti s opskrbnim lancima (Cullinane i Haralambides, 2021). Krajem 2020. godine došlo je do iznimno brzog oporavka u potražnji za kontejnerskim prijevozom robe morem, no ponuda je bila ograničena i troškovi su bili povećani. Navedeno je rezultiralo narušavanjem pouzdanosti usluge te dovođenjem u pitanje učinkovitosti funkcioniranja vrijednosnih lanaca (United Nations, 2021).

Otpornost i prilagodljivost kako cjelokupnog svjetskog gospodarstva, tako i pomorske industrije testiraju određeni ekonomski šokovi. Notteboom i suradnici (2021) su u svrhu utvrđivanja razlike među implikacijima na pandemiju COVID-19 i implikacija velikih šokova sličnih razmjera, kao i procjene otpornosti na pomorskom tržištu proveli primarno i sekundarno istraživanje. Vanjski šok koji je prouzročila pandemija COVID19 brzo je utjecao na sve elemente opskrbnog lanca i to gotovo u isto vrijeme. Otpornost na poremećaje ostaje ključan izazov za globalnu pomorsku industriju. Na svaku krizu s kojom se industrija suoči treba gledati kao na događaj koji omogućuje testiranje prilagodljivosti na okolnosti koje se vrlo brzo mijenjaju. Pandemija COVID-19 potvrdila je izuzetnu pregovaračku moć brodara, a što se reflektiralo kroz porast vozarina na kontejnerskom pomorskom tržištu, ali i u pozitivnom financijskom rezultatu (Notteboom, Pallis i Rodrigue, 2021). U Europi su se troškovi pomorskog prijevoza, nakon izlaska iz izolacije, utrostručili. No bitno je istaknuti kako je ovaj put isključena mogućnost ponovne pojave niskih cijena u svrhu poticanja brzog oporavka kako nacionalnih gospodarstava tako i cjelokupne međunarodne tgovine (TEC CONTAINER, 06.05.2021.).

Neosporno je kako je izbijanje ove pandemije ozbiljno narušilo stabilnost operacija u opskrbnom lancu te poremetilo kontejnersku logistiku (Nwokedi i sur., 2021). U 2021. godini udio kontejnerskih brodova u ukupnoj svjetskoj floti iznosio je 13,20\%, a što ih svrstava na treće mjesto. U odnosu na 2020. godinu (promatrano u DWT) zabilježen je rast od 2,48\%. Brodarska poduzeća prepoznala su potrebu povećanja ponude kapaciteta te su stoga u svrhu mogućnosti zadovoljenja većih potražnji za kotejnerskim prijevozom i u budućim vremenima, početkom 2021. godine naručili nove kontejnerske brodove. 
Tako su nove narudžbe za kontejnerskim brodovima najveće u posljednja dva desetljeća (United Nations, 2021: XVI). No pitanje je da li je skok u narudžbama dijelom nastao kao potreba obvezne primjene goriva s manje sumpora. Odluka o obnavljanju flote poduzeće nikako ne smije donijeti ishitreno, a ista je determinirana različitim čimbenicima koja nisu ista za svako poduzeće na tržištu (Zhao, Ye i Zhou, 2021).

Nwokedi i suradnici (2021) ističu kako je pandemija COVID-19 uzrokovala i disrupcije u kontejnerskom pomorskom prometu u posljednjoj milji (engl. last-mile) odnosno u završnom koraku distribucije robe prema krajnjem potrošaču. Veće disrupcije su se javile u procesima između morskih luka sa tržištima u zaleđu. Donosioci mjera oporavka moraju uzeti u obzir inflatorni utjecaj koji je posljedica povećanih troškova prijevoza kontejnerima posebice u posljednjoj milji (Nwokedi i sur., 2021). Mańkowska i suradnici (2021) su proveli istraživanje u svrhu identifikacije izvora i vrsta poremećaja u različitim opskrbnim lancima na pomorskom tržištu koji su se javili uslijed pandemije COVID-19. Cilj je bio utvrditi kako su isti utjecali na rad različitih vrsta terminala u morskim lukama odnosno na operacije vezane za pojedinu vrstu tereta. Temeljem rezultata istraživanja autori su utvrdili kako su određeni pomorski opskrbni lanci prestali postojati, određeni su bili suočeni sa znatno manjim količinama tereta dok je posljednja kategorija bila suočena s porastom količine za pretovar u odnosu na predpandemijsko doba. Operateri na terminalima potvrdili su kako se s novonastalom situacijom bore primjenom proaktivnih (ofenzivnih) i adaptivnih (obrambenih) mjera. Ono poduzeće koje radi na uključivanju u nove pomorske opskrbne lance te eventualno sudjeluje $u$ uspostavljanju novih pomorskih lanaca proaktivno se nosi s postojećom situacijom. S druge strane, implementacija mjera kao nužan odgovor na promjene koje su se javile u postojećim pomorskim opskrbnim lancima odnosi se na adaptivne odnosno obrambene mjere. Pokazalo se kako odluka o mjerama na koje se odlučuje pojedini sudionik u opskrbnom lancu ovisi prije svega o funkciji koju isti ima unutar opskrbnog lanca (Nwokedi i sur., 2021). Russel, Rumasook i Roso (2020) navode kako je za adekvatan odgovor na poremećaje u opskrbnom lancu bitno uspostaviti fleksibilnost kapaciteta $\mathrm{u}$ kontejnerskim lukama. Fleksibilnost kapaciteta se i u vrijeme ove pandemije pokazuje kao idealan odgovor na disrupcije u opskrbnom lancu. Kako bi se osigurala dovoljna fleksibilnost potrebno je pozornost usmjeriti na statične te prilagodljive komponente kapaciteta u kontejnerskim lukama. Fleksibilnost u statičkim komponentama se temelji na mehanizmima proširenja, dok se fleksibilnost $\mathrm{u}$ prilagodljivim komponentama temelji na prilagodljivim mehanizmima za poboljšanje korištenja postojećih kapaciteta (Russel, Rumasook i Roso, 2020).

Troškovi pomorskog prijevoza u pravilu su veći za manja gospodarstva i to ponajprije zbog nedovoljne povezanosti u linijskom pomorskom prijevozu, lošije kvalitete lučke infrastrukture te primjene neodgovarajućih mjera za podupiranje trgovine. Manje države rješenje u cilju osiguranja nižih troškova mogu tražiti u nadogradnji postojećih luka kako bi povećali kapacitete istih te time omogućili bržu i kvalitetniju uslugu dostave (United Nations, 2021). U svrhu oporavka od pandemije, poduzeća moraju integrirati kratkoročne (krizni tim, 3PL operatori, struktura transportnih troškova, upravljanje transportom, outsourcing, suradnja s dobavljačima, fleksibilniji ugovori) i dugoročne strategije upravljanja rizicima (suradnja u opskrbnom lancu, inteligentni 
transportni sustavi, industrija 4.0, upravljanje dobavljačima, digitalna opskrbna mreža) uz fleksibilno i inovativno korištenje raspoloživih resursa. To će omogućiti bolju zaštitu opskrbnog lanca od budućih disrupcija (Sudan i Taggar, 2021).

\section{KONTEJNERSKO POMORSKO TRŽIŠTE I VOZARINE U KRIZNIM VREMENIMA}

Značajnu ulogu u globalnom prometu ima pomorski promet, a njegov ključni segment predstavlja upravo kontejnerski pomorski prijevoz (Grzelakowski, September 2019). Logistički, kao i ostali gospodarski sektori, uslijed ove pandemije pretrpjeli su gotovo neviđene utjecaje. Četiri su bitne razlike pandemije uzrokovane koronavirusom i ranijih kriza s kojima se je svijet susreo, a to su (Barleta i Sánchez, July 2021):

1. Prethodno postojeći nepovoljni uvjeti. Obujam robne razmjene posljednjih godina raste po znatno nižim stopama nego li u periodu prije krize iz 2008. godine.

2. Ova kriza je globalna i zahvatila je gotovo sva svjetska gospodarstva. Ranije krize su bile više regionalnog karaktera.

3. Najgori učinci krize koja je započela sredinom 2008. godine uslijedili su mjesecima nakon njenog početka dok je kriza započeta 2020. godine odmah značajno uzdrmala svjetsko tržište.

4. Trenutno učinci ove pandemije predstavljaju najveći pad u međunarodnoj trgovini od Drugog svjetskog rata.

Promatraju li se stope rasta svjetske trgovine nakon financijske krize iz 2008. i 2009. godine, razvidno je kako se svjetsko tržište još nije oporavilo od iste. Tako je prosječna stopa rasta u razdoblju od 2012. do 2019. godine iznosila 2,3\%, dok je u razdoblju od 1990. do 2012. godine iznosila 6,2\% (ECLAC, 06.08.2020.). Iako se može reći kako se je tijekom drugogo polugodišta 2020. godine i tijekom 2021. godine svjetska trgovina postupno oporavljala, uočeno je kako je ponuda bila manje elastična te ograničena kašnjenjima i zagušenjima nastalima uslijed pandemije COVID-19 što je potaknulo rast vozarina na kontejnerskom pomorskom tržištu (United Nations, 2021:XVII)

\subsection{Utjecaj kriza na kontejnersko pomorsko tržište}

Kontejnerski pomorski transport sastavni je dio globalizacijskog procesa, a ujedno i važan čimbenik održivog gospodarskog razvoja (Jerebić i Pavlin, 2018). Upravo sposobnost kontejnerskog brodastva da prenese velike količine roba od mjesta proizvodnje u mjesta konačne potrošnje, podupire suvremeni način život. Važnost ove vrste prijevoza ogleda se u činjenici da na razini Europske unije pomorski prijevoz čini $80 \%$ ukupnog izvoza te uvoza (promatrano u volumenu) odnosno 50\% ukoliko se promatra po vrijednosti robe (International Chamber of Shipping, N/A). Kontejnerski transport predstavlja kapitalno intenzivnu industriju u kojoj je imovina ili u vlasništvu ili u najmu. Stoga adekvatno upravljanje kontejnerskom flotom predstavlja ključnu komponentu operativnog te komercijalnog uspjeha kontejnerskih brodskih linija 
(Notteboom, Pallis i Rodrigue, 2021). Posljednjih godina, suvremene opskrbne lance u kontejnerskim lukama odlikuje povećana neizvjesnost uzrokovana nizom čimbenika poput sociekonomskih čimbenika, ali i promjena strategija upravljanja opskrbnim lancem, a sve kao odgovor na promjene u okruženju. Iako su ovi čimbenici utjecali na opskrbne lance i prije, pandemija COVID-19 je dodatno osnažila njihov utjecaj (Russel, Ruamsook i Roso, 2020). Prethodne krize pa tako i ova pandemija potvrdile su otpornost potražnje za osnovnim dobrima $\mathrm{i}$ to prvenstveno prehrambenim i medicinskim proizvodima (Notteboom, Pallis i Rodrigue, 2021).

Usporedba dosad zabilježenih učinaka pandemije COVID-19 s onima iz financijske krize u 2008. i 2009. godini upućuje na idiosinkratične implikacije svake krize na opskrbne lance na pomorskom tržištu. No u vrijeme ove pandemije kod brodara, operatora na terminalima i lukama uočava se veća otpornost nego li u ranijoj krizi Navedeno je vjerojatno rezultat provedenih promjena unutar samih organizacija, ali i boljeg upravljanja rizicima (Notteboom, Pallis i Rodrigue, 2021). Svjetska ekonomska kriza iz 2008. godine rezultirala je kolapsom u proizvodnji i međunarodnoj trgovini. Recesija koja je tada zahvatila cijeli svijet reflektirala se kroz velik pad potražnje za cjelokupnim prijevozom pa je tako i pomorsko tržište bilo u velikoj krizi. Prijašnje krize na kontejnerskom pomorskom tržištu pokazale su kako su poduzeća bila suočena $\mathrm{s}$ (Jerebić i Pavlin, 2018):

1. Prekapacitiranošću teretnog prostora

2. Padom vozarina

3. Vozarinskim ratovima

4. Gubitkom poslova te

5. Zaduživanjem, financijskim gubicima, stečajevima ili propašću poduzeća.

Oporavak od krize iz 2008. godine je dodatno bio narušen isporukama brodova naručenih prije početka iste. Isporuke tih brodova dodatno su povećale ponudu koja je već bila znatno veća od postojeće potražnje. Posljedice prekapacitiranosti i pada u proizvodnji i trgovini u cijelom svijetu su se odrazile na drastičan pad vozarina na kontejnerskom pomorskom tržištu. Ono što se pokazalo kao ozbiljan problem za vrijeme krize u 2008. i 2009. godini je spuštanje cijena ispod granice likvidnosti, a što su provodili veliki igrači. Cilj te politike je isključivo bio opstanak na tržištu te ugrožavanje drugih sudionika. Dugoročno ta politika može samo stvoriti dodatne gubitke, a i u konačnici rezultirati propašću poduzeća (Jerebić i Pavlin, 2018). Financijska kriza iz 2008. godine pokazala je koliko je ranjivo ovo tržište te je za lakše savladavanje budućih kriza bitno uspostaviti adekvatne infomacijsko komunikacijske kanale. Brodari moraju uspostaviti odgovarajuće djelovanje informacijskog mehanizma prilagođavajući ga različitim vrstama informacija koje planiraju primati (Min, Wang i Zhan, 2009: 166).

Reakcije na prijašnje krize na kontejnerskom tržištu pokazale su kako je svaka imala drugačije posljedice. Pandemija COVID-19 nije ograničena samo na pojedine regije ili da joj je ograničeno vrijeme djelovanja. Ova pandemija zahvatila je cijeli svijet, a uslijed iste su različite komponente proizvodnje, distribucijskih centara, logistike kao i tržišta narušile stabilnost opskrbnih lanaca (Tucker, 03.05.2020). Pandemija COVID-19 utjecala je na globalne opskrbne lance te na lučku i cjelokupnu brodarsku industriju kako ranije nije bilo zabilježeno. Prijašnja iskustva pokazala su kako svaki iznenadni pad u 
potražnji potrošača ima neposredan utjecaj na razne aktivnosti na pomorskom tržištu kao i na lučke operacije (Notteboom, Pallis i Rodrigue, 2021).

Strategije kojima se poduzeća na ovom tržištu trebaju prikloniti u kriznim vremenima su (Jerebić i Pavlin, 2018: 190-192):

1. Konsolidacija kapaciteta (primjerice kroz smanjenje brzine plovidbe).

2. Optimizacija i redukcija operativnih troškova (engl. Optimization and Operating Expenses Reduction - OPEX). Glavni operativni troškovi koji trebaju biti u fokusu redukcije su troškovi goriva i maziva, posade, održavanja, rezervnih dijelova i potrošnog materijala.

3. Ekonomija obujma. Ovo nije nepoznanica na kontejnerskom pomorskom tržištu, ali je vrlo teško ostvarivo zbg visokih financijskih ulaganja potrebnih za ostvarenje ekonomije obujma.

4. Integracije. Ranije su linijske konferencije bile odgovorne za kontrolu tarifa na određenim rutama. No posljednjih desetak godina, sve je više trgovinskih strateških saveza koji dijele informacije, resurse i kontrolu kako bi povećai opseg poslovanja.

Za razliku od prijašnjih kriza evidentno je da su donosioci odluka u vrijeme ove pandemije prisiljeni donositi teške odluke i da djeluju zapravo u neistraženim uvjetima (Nikolopoulos i sur., 2021). Poremećaji koje je ova pandemija prouzročila u ponudi i potražnji ukazuju na potrebu uspostave visokog stupnja fleksibilnosti kako bi se ublažili rizici od epidemije te od oscilacija u potražnji (McMaster i sur., 2020).

\subsection{Vozarine na kontejnerskom pomorskom tržištu u pandemijsko doba}

Posljednjih mjeseci premještanje robe na glavnim rutama pomorskog prometa stvara velike probleme logističkim odjelima u poduzećima diljem svijeta. Troškovi prijevoza pomorskim putem povećali se za 3 puta otkad je Europa bila u 'lockdownu', a nekoliko faktora je utjecalo na to:

1. Uslijed ograničenja kretanja koji je na snazi bio u većini svjetskih zemalja, brojna brodarska poduzeća bila su suočena sa slanjem brodova na rute, a da su pri tome imali puno slobodnog kapaciteta što zbog otkazivanja narudžbi što zbog smanjenja količine od strane nekih poduzeća.

2. Kina je bila suočena sa rastom volumena robe namijenjene izvozu u glavne svjetske luke. U brojnim svjetskim lukama brodovi su bili suočeni s dugim čekanjem na iskrcaj, što se odrazilo na nizak stupanj rotacije kontejnerskih brodova, a potom i na rast cijene u ugovorima za pomorski kontejnerski prijevoz robe.

3. Početkom 2020. godine vozarine su rasle zbog odredbi koje je Međunarodna pomorska organizacija (engl. International Maritime Organization) nametnula brodarima, a tiču se promjene goriva . Tako su od 01. siječnja 2020. godine obvezne su koristiti VLSFO (engl. Very Low Sumpor Fuel Oil) odnosno gorivo vrlo niskog sumpora. Razina sumpora koju brodovi koriste prilikom plovidbe ne smije biti veća od 0,5\% m/m (Iternational Maritime Organization, 05.12.2018.). 
Tijekom posljednjih godinu i pol dana stopa za jedan pomorski kontejner naglo je porasla uslijed poremećaja kako opskrbnih tako i trgovinskih lanaca (Cheng, 18.11.2021). Neizvjesnost koja danas karakterizira kontejnersko pomorsko tržište najveća je otkad je započet proces kontejnerizacije (Russel, Ruamsook i Roso, 2020). Upravo je neusklađenost između rastuće potražnje te smanjenog kapaciteta opskrbe potaknula rast vozarina na svim kontejnerskim pomorskim rutama. Rast potražnje bio je znatno veći od očekivanoga (UNCTAD, 2021/040). Unatoč tome što rast vozarina sugerira da tržište uspješno upravlja opskrbom te da rastom cijene nadoknađuje pad potražnje, najveći dio ključnih igrača na tržištu zatražio je financijsku pomoć od svoje države. Preciznije, čak 6 od najvećih 10 brodarskih poduzeća je postupilo tako i to su CMA CGM, COSCO Shipping Lines, HMM, Evergreen Marine, Yang Ming i Pacific International Lines (ECLAC, 06.08.2020.: 14).

Grafikon 1. Kretanje 'New ConTex' indeksa u periodu od 01.01.2012.-20.11.2021.



Izvor: prilagodba autora prema podacima s https://www.vhbs.de/index.php?id=5\&L=1

$\mathrm{Na}$ grafikonu 1 prikazano je kretanje New ConTex ${ }^{18}$ indeksa od 01. siječnja 2012. godine do 20. studenog 2021. godine, a na kojem se može uočiti kako je rast indeksa započet u posljednjem kvartalu 2020. godine te je eksponencijalni rast nastavljen sve do rujna ove godine. Tijekom rujna i listopada 2021. godine nije bilo nekih većih kolebanja, a početkom studenog nakon dugog vremena zabilježen je pad.

Utjecaj porasta vozarina u kontejnerskom pomorskom prometu ne samo da dovodi u pitanje brzinu i upitnost oporavka cjelokupnog svjetskog tržišta od pandemije, već (UNCTAD, 2021: 66-69):

1. Uzrokuje porast uvoznih i potrošačkih cijena.

2. Varijacije u cijenama utječu na cjelokupna gospodarstva i razna dobra te nisu karakteristični samo za slabije razvijene zemlje ili zemlje u razvoju.

3. Utječe na globalnu proizvodnju kao i troškove.

\footnotetext{
${ }^{18}$ New ConTex je indeks fiksnog zakupa broda za kontejnerski prijevoz koji je nezavisan od poduzeća. Ovisi o dnevnoj procjeni cijene zakupa šest odabranih tipova kontejnerskih brodova koji predstavljaju kategorije njihovih veličina i to tipovi 1100 TEU i 1700 TEU za period najma od 1 godine te tipovi 2500, 2700, 3500 i 4250 TEU za period najma od 2 godine. Od 01.08.2011. godine ovaj indeks ne uključuje samo poznate podatke već i prognoze.
} 
Grafikon 2.Top 10 proizvoda široke potrošnje prema predviđenom porastu cijene (\%)

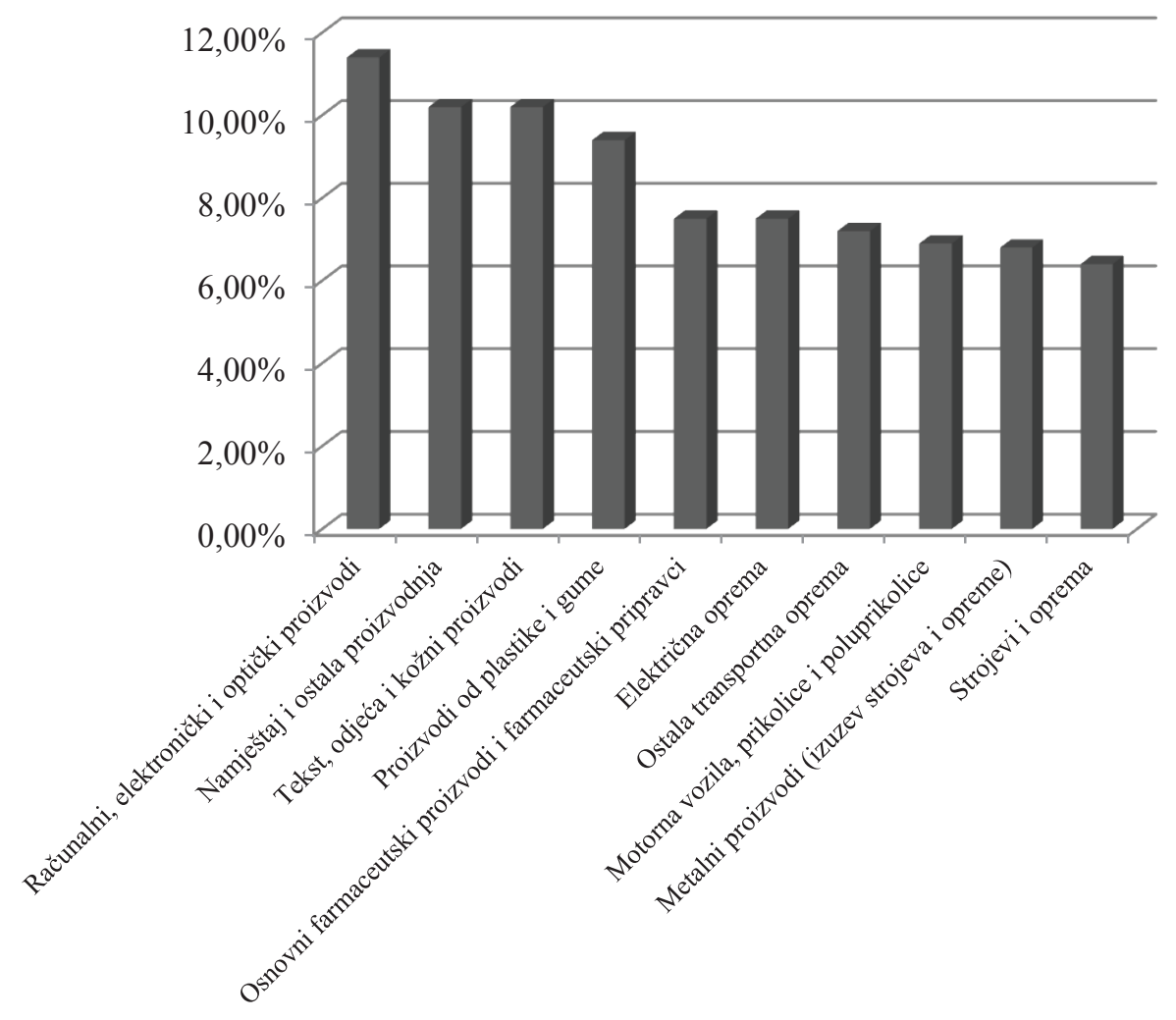

Izvor: izrada autora prema United Nations (2021). Review of maritime transport 2021, str. 68

$\mathrm{Na}$ grafikonu 2 prikazano je top 10 proizvoda široke potrošnje prema predviđenom porastu cijene iskazanom u postotku. Najveći porast cijena previđa se za računalne, elektroničke i optičke proizvode. Razlog tomu je što se najveći dio tih proizvoda proizvodi u istočnoj Aziji te stoga moraju prevaliti veliki put do mjesta svoje krajnje potrošnje. Više vozarine ne utječu jednako na porast svih potrošačkih cijena. Veći utjecaj imaju na porast cijena onih proizvoda koji su u većoj mjeri integrirani u globalne opskrbne lance (United Nations, 2021). Promjene u obrascima potrošnje prije svega su vezane i za vrstu robe ili usluge. Tako osnovna (nužna) dobra poput hrane, kao i luksuzna dobra u pravilu imaju najveću otpornost (Notteboom, Pallis i Rodrigue, 2021). Ovaj rast vozarina na kontejnerskom pomorskom tržištu mogao bi u prosjeku povećati potrošačke cijene za $1,5 \%$ u sljedećoj godini. Taj rast biti će znatno viši u državama koje su uvozno ovisne (Cheng, 18.11.2021.). 
Porast vozarina odrazit će se i na troškove proizvodnje što u konačnici može utjecati na dinamiku razvoja nacionalnih gospodarstava. Za očekivati je kako ovaj utjecaj neće biti jednako rasporođen, već će zasigurno biti veći za manja gospodarstva (UNCTAD, 2021/040). Rast vozarina u kontejnerskom pomorskom prometu za 10\% popraćen disrupcijama u opskrbnim lancima, rezultirat će padom industrijske proizvodnje u Sjedinjenim Američkim Državama i Euro zoni za više od 1\% (United Nations, 2021: 69). Iako su Sjedinjene Američke Države od srpnja 2021. godine počele bilježiti oporavak industrijske proizvodnje praćen snažnim rastom osobne potrošnje, industrijska proizvodnja i dalje bilježi negativnu stopu rasta. Navedeno najbolje implicira kako upravo disrupcije na kontejnerskom pomorskom tržištu dovode u pitanje brzinu oporavka svjetskog gospodarstva (United Nations, 2021:70).

Grafikon 3. Simulacija utjecaja trenutnih vozarina na kontejnerskom pomorskom tržištu na uvozne i potrošačke cijene



Izvor: izrada autora prema United Nations (2021). Review of Maritime Transport 2021, str. XVII

Predviđanja u vezi postotnih promjena cijena za pojedinu kategorije zemlje, prikazana su na Grafikonu 3. U nerazvijenim zemljama predviđa se rast od $8,7 \%$ za cijene uvoznih roba. Najveći rast, kako u potrošačkim tako i u uvoznim cijenama, previđen je 
za manje otočne države koje su još u fazi razvoja. Dok se na svjetskoj razini predviđa porast za cijene uvoznih dobara u prosjeku od 10,6\%, kod malih otočnih država u razvoju je predviđen rast od visokih $24,2 \%$.

\section{ZAKLJUČAK}

Značajnu ulogu u funkcioniranju svjetskog gospodarstva ima pomorski promet, a ključni segment predstavlja upravo kontejnerski pomorski prijevoz. Kontejnerski pomorski prijevoz dominira prije svega zbog svoje ekonomičnosti te učinkovitosti. Kontejnerski brodovi podupiru suvremeni način života prijevozom velikih količina roba iz mjesta proizvodnje u mjesta konačne potrošnje. No, kako je pandemija COVID-19 utjecala na cjelokupni svijet, tako nije zaobišla niti ovo tržište. Iako su oscilacije u potražnji na ovom tržištu uobičajena pojava te su brodarske kompanije spremne na to, ovakvu volatilnost u potražnji nitko nije mogao predvidjeti. Uslijed visoke volatilnosti u potražnji te popraćeno odredbama Međunarodne pomorske organizacije o obvezi korištenja goriva s manje sumpora, ali i zatvaranjem Sueskog kanala, vozarine na kontejnerskom pomorskom tržištu zabilježile su rekordne razine.

Pomorskim putem preveze se više od $80 \%$ svjetske robne razmjene stoga je iznimno važno osigurati stabilnost na istom. Oporavak cjelokupnog svjetskog gospodarstva ugrožen je snažnim rastom vozarina u pomorskom kontejnerskom prometu, a stvara i dodatne poremećaje u opskrbnom lancu. Rast vozarina na ovom tržištu utjecat će kako na troškove proizvodnje tako i na rast cijena proizvoda koje ovisi o njegovim uslugama. Očekuje se kako će veći porast biti upravo u manjim gospodarstvima te će u velikoj mjeri i utjecati na dinamiku oporavka pojedinih nacionalnih goposdarstava. Koliki će biti utjecaj na rast cijena proizvoda ponajprije ovisi o uključenosti pojedinog proizvoda u globalne opskrbne lance.

Ključan izazov za globalnu pomorsku industriju ostaje uspostava otpornosti na poremećaje. Poduzeća moraju uspostaviti veću fleksibilnost kapaciteta kako bi u budućim krizama manje osjećala poremećaje. Upravo se je fleksibilnost kapaciteta i u vrijeme ove pandemije pokazala kao idealan odgovor na disrupcije u opskrbnom lancu. Fleksibilnost se može povećati usmjeravanjem na statične te prilagodljive komponente kapaciteta $\mathrm{u}$ kontejnerskim lukama. Za lakše savladavanje budućih kriza bitno je uspostaviti i adekvatne infomacijsko komunikacijske kanale. Naodmet nije niti integracija kako kratkoročnih tako i dugoročnih strategija upravljanja rizicima jer će to osigurati dodatnu zaštitu od potencijalnih budućih disrupcija.

\section{LITERATURA:}

1. Barleta, E. P., Sánchez, R. J. (July 2021). Port Report: the impact of the coronavirus disease (COVID-19) pandemic on the shipping trade, trans-shipment and throughput of container ports in Latin America and the Caribbean, Bulletins, br. 2 (2021). 
https://repositorio.cepal.org/bitstream/handle/11362/47017/1/S2100301_en.pdf (22.08.2021.).

2. Cheng, E. (18.11.2021.). Surging shipping costs will drive up prices for some consumer products by $10 \%$, new UN report finds, CNBC. Dostupno na: https://www.cnbc.com/2021/11/19/surging-shipping-costs-to-drive-consumerprice-inflation-unctad-says.html (23.11.2021.).

3. Cullinane, K., Haralambides, H. Global trends in maritime and port economics: the COVID-19 pandemic and beyond, Marit Econ Logist, 23(September), str. 369-380. https://doi.org/10.1057/s41278-021-00196-5

4. Economic Commission for Latin America and the Caribbean (ECLAC) (06.08.2020). The effects of the coronavirus disease (COVID-19) pandemic on international trade and logistics, Bulletins, br. 6. Dostupno na: https://repositorio.cepal.org/bitstream/handle/11362/45878/1/S2000496 en.pdf (23.06.2021.).

5. Grzelakowski, A. S. (2019). Global container shipping market development and its impact on mega logistics system, TransNav: International Journal on Marine Navigation and Safety of Sea Transportation, 13(3), str. 529-535. https://doi.org/10.12716/1001.13.03.06

6. International Chamber of Shipping (N/A). Shipping and world trade: driving prosperity. Dostupno na: https://www.ics-shipping.org/shipping-fact/shipping-andworld-trade-driving-prosperity/ (12.06.2021.).

7. International Maritime Organization (05.12.2018.). Tehnical Circular, No. 087/2018. Dostupno na: https://www.irclass.org/media/3880/technical-circularno87.pdf (19.06.2021.).

8. Jerebić, V., Pavlin, S. (2018). Global Economy Crisis and its Impact on Operational Container Carrier's Strategy, Promet-Traffic\&Transportation, 30(2), str. 187-194. https://doi.org/10.7307/ptt.v30i2.2440

9. McMaster, M., Nettleton, C., Tom, C., Xu, B., Cao, C., Qiao, P. (2020). Risk management: Rethinking fashion supply chain management for multinational corporations in light of the COVID-19 outbreak, Journal of Risk and Financial Management, 13(8), 173. https://doi.org/10.3390/jrfm13080173

10. Min, D., Wang, F., Zhan, S. (2009, June). Impact analysis of the global financial crisis on global container fleet, U: (Ji, G., Chen, J., Miao, Z., Wu, L., Yang, F., Li, P. (Ur.) Proceedings of ICSSSM'09, Xiamen: Reearch Centre for Contemporary Management (Xiamen University) \& Key Research Institute of Humanities and Social Sciences at Universities, str. 161-166). IEEE. https://doi.org/10.1109/icsssm.2009.5174875

11. New ConTex. A benchmark for the container market (online), dostupno na https://www.vhbs.de/index.php?id=28\&L=1 (23.11.2021.).

12. Nikolopoulos, K., Punia, S., Schäfers, A., Tsinopoulos, C., Vasilakis, C. (2021). Forecasting and planning during a pandemic: COVID-19 growth rates, supply chain disruptions, and governmental decisions, European journal of operational research, 290(1), str. 99-115. https://doi.org/10.1016/j.ejor.2020.08.001 
13. Notteboom, T., Pallis, T., Rodrigue, JP. Disruptions and resilience in global container shipping and ports: the COVID-19 pandemic versus the 2008-2009 financial crisis, Marit Econ Logist, 23(January), str. 179-210. https://doi.org/10.1057/s41278-020-00180-5

14. Nwokedi, T. C., Okoroji, L. I., Nwoloziri, C. N., Efanga, H. O., Okafor, C. O. (2021). COVID-19: Disruption of Container Freight Transportation on Last Mile Corridors between Regional Hub Ports and Hinterland Markets in Nigeria, Himalayan Journal of Economics and Business Management, 2(1), str. 1-13. https://doi.org/10.47310/Hjebm.2021.v02i01.001

15. Russell, D., Ruamsook, K., Roso, V. (2020). Managing supply chain uncertainty by building flexibility in container port capacity: a logistics triad perspective and the COVID-19 case, Maritime Economics \& Logistics, 14(4), str. 1-22. https://doi.org/10.1057/s41278-020-00168-1

16. Stevens, P. (29.03.2021.). The ship that blocked the suez Canal may be free, but experts warn the supply chain impact could last months, CNBC. Dostupno na: https://www.cnbc.com/2021/03/29/suez-canal-is-moving-but-the-supply-chainimpact-could-last-months.html (18.06.2021.).

17. Sudan, T., Taggar, R. (2021). Recovering Supply Chain Disruptions in PostCOVID-19 Pandemic Through Transport Intelligence and Logistics Systems: India's Experiences and Policy Options. Frontiers in Future Transportation, Vol. 2, Article No. 660116. https://doi.org/10.3389/ffutr.2021.660116

18. TEC CONTAINER (06.05.2021.). 3 reasons for the rise in the price of maritime transport (online). Dostupno na: https://www.teccontainer.com/blog/rise-in-theprice-of-maritime-transport/ (27.08.2021.).

19. Tucker, H. (03.05.2020). Coronavirus Bankruptcy Tracker: These Major Companies are Failing Amid the Shutdown, Forbes. Dostupno na https://www.forbes.com/sites/hanktucker/2020/05/03/coronavirus-bankruptcytracker-thesemajor-companies-are-failing-amid-the-shutdown/ (18.07.2021.).

20. UNCTAD Communications and Information Unit (2021). High freight rates cast a shadow over economic recovery, PR. 2021/040. Dostupno na: https://unctad.org/press-material/high-freight-rates-cast-shadow-over-economicrecovery (28.11.2021.).

21. United Nations (2020). Review of Maritime Transport 2020, New York: United Nations Publications. Dostupno na: https:/unctad.org/system/files/officialdocument/rmt2020 en.pdf $(25.06 .2021$.).

22. United Nations (2021). Review of maritime transport 2021, New York: United Nations Publciations. Dostupno na: https://unctad.org/system/files/officialdocument/rmt2021 en 0.pdf (02.09.2021.).

23. World Health Organization (11.03.2020.). WHO Director-General's opening remarks at the media briefing on COVID-19 - 11 March 2020. Dostupno na: https://www.who.int/director-general/speeches/detail/who-director-general-sopening-remarks-at-the-media-briefing-on-covid-19---11-march-2020 (23.06.2021.). 
POSLOVNA IZVRSNOST ZAGREB, GOD. XV (2021) BR. 2 Naletina D.: Volatilnost vozarina u kontejnerskom pomorskom prometu u doba pandemije...

24. Zhao, Y., Ye, J., Zhou, J. (2021). Container fleet renewal considering multiple sulfur reduction technologies and uncertain markets amidst COVID-19, Journal of Cleaner Production, $\quad$ Vol. 128361. https://doi.org/10.1016/j.jclepro.2021.128361 


\title{
FREIGHT VOLATILITY IN CONTAINER MARITIME TRANSPORT DURING THE COVID-19 PANDEMIC
}

\section{Dora Naletina}

\begin{abstract}
Summary
In recent years, the stability of supply chains has been threatened by various dangers. Although the supply chain disruptions happen to occur from time to time, they deeply impact the increase of costs and create strong disturbances in business activities. The COVID-19 pandemic has shaken the global supply chain like nothing has before. Not even those companies with highly advanced systems for risk management could not respond adequately to such a sudden blow. For years, the majority of world trade has been carried out via the sea, mostly due to the efficiency and cost-effectiveness this mode of transport offers. The market has been affected with a great deal of changes prompted by the COVID-19 pandemic, resulting in the maritime shipping rates growing to unprecedented levels. The growth of the freight rates on this market represents a global issue, because it is influencing the prices of different consumer goods, relative to their inclusion in the supply chains. Such high rates in maritime shipping calls the recovery of the entire global economy into question and additionally, endangers the stability of the supply chains. In line with this, the focus of this paper is the volatility of the shipping rates in maritime container freight market that has occurred due to the COVID-19 pandemic.
\end{abstract}

Keywords: disruptions; supply chain; maritime container traffic; COVID-19 pandemic. 